\title{
Effects of provenance, pre-treatment and seeds' mass on germinability and seedling growth of socio- economically important Balanites aegyptiaca (L.) Delile and Ricinodendron heudelotii (Bail.) Pierre in Benin (West Africa)
}

Guillaume HOUNSOU-DINDIN ( $\sim$ guillaumehdd@gmail.com )

Laboratoire de Biomathématiques et d'Estimations Forestières https://orcid.org/0000-0002-2410-7940

\section{Rodrigue Idohou}

Laboratoire de Biomathématiques et d'Estimations Forestières (LABEF/FSA/UAC) \& Ecole de Gestion et de Production Végétale et Semencière (EGPVS/UNA)

\section{Marcel T. Donou Hounsode}

Laboratoire de Biomathématiques et d'Estimations Forestières (LABEF/FSA/UAC)

\section{Aristide C. Adomou}

Laboratoire de Botanique et Ecologie Végétale (LaBEV/FAST/UAC)

Achille E. Assogbadjo

Laboratoire de Biomathématiques et d'Estimations Forestières (LABEF/FSA/UAC) \& Laboratoire d'Ecologie Appliquée (LEA/FSA/UAC)

\section{Romain Glèlè Kakaï}

Laboratoire de Biomathématiques et d'Estimations Forestières (LABEF/FSA/UAC)

\section{Research Article}

Keywords: basal diameter, height, leaf, phytodistrict, ramification, survival rate

Posted Date: June 28th, 2021

DOl: https://doi.org/10.21203/rs.3.rs-654923/v1

License: (c) (i) This work is licensed under a Creative Commons Attribution 4.0 International License. Read Full License 


\section{Abstract}

Balanites aegyptiaca (L.) Delile and Ricinodendron heudelotii (Bail.) Pierre are socioeconomically important but endemic species to sub-Saharan Africa. This study was conducted to assess the germination capacity of their seeds and seedling growth according to seed provenance, seed mass and pre-treatment techniques as a contribution to the development of strategies for their conservation and domestication in Benin. The seeds were randomly collected in the species occurrence phytodistricts. A split-split plot design with three replicates was used. The survival analysis and generalized linear mixed effects models were implemented on the data. Findings were that the heaviest seeds ( B. aegyptiaca seed mass $\geq 3 \mathrm{~g}$ and $\mathrm{R}$. heudelotii $\geq 1.50 \mathrm{~g})$, provided the highest germination rates $(73.60 \pm 5.19 \%$ and 62.50 $\pm 5.71 \%$ ) with seeds scarified with a hammer first emerging at day-8 and day-10 for B. aegyptiaca and R. heudelotii respectively. For $B$. aegyptiaca seedlings, the seeds from North Borgou phytodistrict scarified with a hammer and the heaviest seeds showed the highest total height $(36.43 \pm 1.03 \mathrm{~cm})$, basal diameter $(2.84 \pm 0.03 \mathrm{~mm}$ ), the greatest number of leaves (32) and ramifications (1). The heaviest seeds of $R$. heudelotii showed also the highest total height from the day-28 after sowing $(26.73 \pm 13.56 \mathrm{~cm})$ until the day-105 $(151.97 \pm 6.37 \mathrm{~cm})$ and those from Pobe phytodistrict showed the highest basal diameter (12.53 $\pm 1.47 \mathrm{~mm}$ ) and the greatest number of leaves (14), with almost no ramification during the trial period. These findings constitute a step towards upscaling the reproducibility of these species for better contribution to economies while serving for restoration plans.

\section{Introduction}

Changes in components of biodiversity cause concern for ethical and aesthetic reasons, but they also have a strong potential to alter ecosystem properties and the goods and services they provide to humanity (Hooper et al. 2005). The wildly available resources from some tree species seem not to be sufficient to sustain the growing demand, since large numbers of these people are facing chronic food insecurity even in growing season (Hounsou-Dindin et al. 2018). For two decades we have witnessed a decrease in rainfall and its poor spatial and temporal distribution. This scourge has the consequences of reducing water potential, deforestation, the scarcity or even the disappearance of certain forest species. Biodiversity needs to be promoted to improve regulation services at the landscape level (soil fertility, water infiltration, etc.) and because, the goods and services provided by the ecosystems is important for local people's livelihoods, their food security and adaptation to climate changes. In the current context of climate changes, the practices are changing to seek ways for mitigation. Recently, the practice of fallows, which contributes to soils restoration elsewhere has received little attention from farmers due to the increasing population pressure on arable land (Kumar and Nair 2011). Plantation forests, initiated some decades ago (1970s) using exotic species such as Eucalyptus camaldulensis Denh., Gmelina arborea Roxb., and Tectona grandis L.f., although not widely spread today, are still encountered, but the new trend is towards tree crop species like cashew (Anacardium occidentale L.) and mango (Mangifera indica L.). Other common tree-related land use types in the country are parklands, which are agroforestry areas, similar to natural savannah where mature trees of a range of species (Vitellaria paradoxa $\mathrm{C}$. F. 
Gaertn., Parkia biglobosa (Jacq.) R.Br. ex Benth., Adansonia digitata L., Faidherbia albida (Delile) A. Chev.) are preserved and among which annual crops are planted (Bayala et al. 2014).

Balanites aegyptiaca (L.) Delile and Ricinodendron heudelotii (Bail.) Pierre are two socio-economically and culturally important wild oil plants which distinctly covered the three climatic zones of Benin: $B$. aegyptiaca is concentrated in the semi-arid zone and $R$. heudelotii (Bail.) covers the sub-humid and humid zones of the country. Unfortunately, the population of these species continues to decrease significantly and the over-exploitation or over-grazing added to the effects of climate change constitute the leading factors of their loss (Hounsou-Dindin et al., unpublished data). Taking them into account in this study is very useful and will be a decisive tool in the choice and national development policies of the oilseed sector.

Successful plant domestication strategies in the tropical areas involves the correct choice of provenances for a successful establishment and optimum productivity of the species (Boyle et al. 1997). The geographic location of a seed source is called its provenance, within tree species provenances, traits may vary; e.g., in growth and adaptability (Fredrick et al. 2015). The natural distribution of some tree species covers large areas; while other species have a limited natural distribution. Some species show large morphological variation and some species are more uniform. The phytodistricts reflect a variation in environmental conditions (Adomou et al. 2006) and offer the opportunity to test the link between individuals in each area.

Seed size is considered to be an indicator of seed quality (Padonou et al. 2013). Seed mass within a species is considered to be a remarkably perpetual characteristic, due to the variation in seed size and mass within species (Quero et al. 2007). Such seed mass variation may affect seedling growth and, then, recruitment process. Large sized seeds were shown to germinate faster than smaller seeds (Das et al. 2016). However, some reversed cases were also reported where small seeds germinated more rapidly than large seeds, e.g., Impatiens capensis Meerb. (Howell 1981). Thus, the performance of seeds and the resulting seedlings may vary from one phytodistrict to another due to the variation in their pedoclimatic conditions. The germinative aptitude of seeds can be influenced by the morphology of the seeds (Padonou et al. 2013) or of the fruit of which they come (Idohou et al. 2015).

Several species showed interesting responses to the mechanical/manual pre-treatments of seeds (scarification), chemical (using nitric or sulphuric acid) or thermic (soaking with hot, tepid, pain tap or cold water) throughout certain time which can go from a few minutes to several hours or days (FAO 1992). For many tropical species, special seed pre-treatment is often necessary to improve the germination rate. The pre-treatments do not germinate the seeds, but make them capable of germinating later when all the required conditions are met (FAO 1992). These pre-treatments by their mechanical, chemical, physiological effects (isolated or associated) make it possible to break dormancy (FAO 1992). $B$. aegyptiaca and $R$. heudelotii are recalcitrant seeds which need prior pre-treatment to improve their germinability. In this study, only the mechanical/manual and thermic pre-treatments techniques of seeds were tested. The exclusion of chemical techniques is primary due to the lack to date of a device to 
neutralize debris or chemical deposits, whether in humans who handle them but also in productions. This constitutes a great risk for public health (from producer to consumer) of which the most cited dangerous diseases are: cancer, mutations or reproductive problems (Samb and Schiffers 2003).

This study was undertaken to compare the rates of germination and seedling growth according to seed provenance, seed mass and pre-treatment techniques. Specifically, the research aims to describe: (i) variability of seeds' mass of $B$. aegyptiaca and $R$. heudelotii in the study zones, (ii) effect of seed pretreatment, seed mass and provenance on germination rate of $B$. aegyptiaca and $R$. heudelotii, and (iii) effect of seed pre-treatment, seed mass and provenance on seedling growth for their large-scale productions.

\section{Methodology}

\section{Study area}

The trial was carried out on the experimentation site of the Laboratory of Biomathematics and Forest Estimations (LABEF), located in the subdistrict of Sékou, district of Allada. The climate is of the subequatorial type with two (02) rainy seasons, a large season, from March to June and a small season, from September to November and two (02) dry seasons, from July to September and from November to March. The mean annual rainfall is $1100 \mathrm{~mm}$ with ferrallitic soils (Adomou et al. 2006). The seeds were collected in the species occurrence phytodistricts of Benin. Three phytodistricts were prospected for each species: Atacora chain, Mekrou-Pendjari and North Borgou phytodistricts in semi-arid zone for $B$. aegyptiaca, and South Borgou phytodistrict in sub-humid zone and Plateau and Pobe phytodistricts in humid zone for $R$. heudelotii (Fig. 1). These phytodistricts were those in which B. aegyptiaca and $R$. heudelotii are present and abundant (Hounsou-Dindin et al., unpublished data).

\section{Sampling and fruits' collection}

Each phytodistrict (Atacora chain, Mekrou-Pendjari and North Borgou phytodistricts for $B$. aegyptiaca and South Borgou, Plateau and Pobe phytodistricts for $R$. heudelotii) was prospected for seed collection (Fig. 1). A total of thirty (30) adult trees at the stage of optimal morphological and physiological maturity (in the fruiting period) were randomly selected in each phytodistricts for $B$. aegyptiaca. As regards $R$. heudelotii, ten (10) trees were randomly selected per phytodistrict. This lower number of trees was considered for $R$. heudelotii because no more trees were found at fruiting stage during data collection especially in the phytodistricts of Plateau and Pobè. For each species, a distance of at least $100 \mathrm{~m}$ was considered between sampling trees in order to minimize the possibility of collecting seeds from genetically closed trees. A total of 30 ripe and apparently unaffected fruits were randomly collected per tree and stored in dry bags per tree. Seeds were extracted and 30 seeds were sampled per tree and their masses were measured using a precision balance (sensitivity $0.01 \mathrm{~g}$ ). Finally, nine (09) plastic boxes were used to soak the seeds for the three (03) seed mass classes of each phytodistrict. Four (04) seeds were selected per seed mass classes, with 12 per pre-treatment, 24 per phytodistrict and 72 per block. A total of 216 seeds were used for the 54 experimental units of each species. 


\section{Experimental design and data collection}

The seeds of both species exhibit exogenous or integumentary (physical) dormancy at germination. As such, two recommended pre-treatment techniques were tested. Seeds of each species were soaked in tap water for 72 hours (T1) and scarified with a hammer (T2). This manual scarification (T2) consists to physically open (slightly damaged) the seed coat to allow moisture and air in. Both pre-treatment techniques were identified as adequate with high germination rates: $50-90 \%$ for $B$. aegyptiaca (Boubacar et al. 2018; Kouyaté et al. 2015) and 63-88\% for R. heudelotii (Djeugap et al. 2013; Kouame et al. 2012). Viable seeds (i.e., able to germinate when conditions are right, provided that any dormancy has been broken) were selected from a viability test following the method of (Assogbadjo et al. 2010). This test involves submerging the seeds in plain water for 24 hours and removing any that float on the surface. The separation of viable seeds and their pre-treatment ensure a high germination rate.

The seeds were sown in black polyethylene bags $(12 \times 18 \mathrm{~cm})$ filled with substrate from the test site (Sékou) with one seed per pot at a depth of 1 to $1.5 \mathrm{~cm}$ from the surface. The pots were aligned in the nursery using a split-split plot with three replicates. The factors were randomized per unit. A total of 216 pots were used per species for the alignment of the 18 treatments ( 03 phytodistricts $\times 02$ pre-treatments $\times$ 03 seed mass classes) considered in the trial (Table 1), at the rate of 04 pots per treatment with the three replicates (Appendix). The pots were watered for 3 days before sowing.

After sowing, the pots were watered twice a day, in the morning and in the evening (cool hours of the day) after sowing, using the watering can. Regular maintenance (weeding) of the site was carried out. Seeds' germination was monitored every day for 28 days (Boubacar et al. 2018; Kouame et al. 2012). The seed was considered germinated when emergence of cotyledons was observed.

The basal diameter (measured using a caliper), the total height (measured with a ruler of $150 \mathrm{~cm}$ ) and the total number of leaves and ramifications of each seedling were recorded every day-7 (a week) from the day-28 after sowing for three (03) months (September 2020 to January 2021 and from December 2020 to April 2021 respectively for $R$. heudelotii and $B$. aegyptiaca due to the availability period of the seeds of each species).

\section{Data analysis}

Seed mass variability: Phytodistricts were compared using analysis of variance followed by a StudentNewman and Keuls tests. The quantiles $(1 / 3$ and $2 / 3)$ of the mass of seeds were calculated and the seeds were grouped into three different mass classes (P1, P2 and P3) for each species.

Germination rate: Data were processed with survival model. To define the survival rate, two variables ("time" and "seeds vital status at the end of the study") were considered. The time indicated the duration of the seed germination and the duration of observation for non-germinated seeds (right censorship). The second variable indicated whether the seeds vital status at the end of the study $(1=$ germinated, and $0=$ non germinated). The predictor variables which were assumed to influence the germination ability of $B$. 
aegyptiaca and $R$. heudelotii seeds in the model are phytodistrict, seed mass class $(\mathrm{P})$ and pre-treatment $(T)$. In order to better appreciate the influence of factors (Table 1 ) on the germination rate, the analysis of the germination time was used with the non-parametric Kaplan-Meier model (McNair et al. 2012) using survival (Therneau 2021) and survminer (Kassambara et al. 2021) packages. This model is appropriate in the context of this study which aims to compare the groups of seeds and avoid any dependence of parametric assumptions on the shape of the hazard or survival, without requiring that the time intervals be regular (McNair et al. 2012).

Initial growth of seedlings: In this model, the factor "block" was considered to be random, whereas all the others ("phytodistrict", "pre-treatment" and "seed mass class" were considered as fixed (Table 1). Linear and generalized linear mixed-effects models for longitudinal data with normal distribution of errors were implemented on growth data using nIme (Pinheiro et al. 2021) and MASS (Venables and Ripley 2002) packages. In these models, provenance (phytodistricts), seed mass class and pre-treatment were considered fixed factors and block as a random factor. The existence of the effect of block and time in the data was tested using the intra-class correlation coefficient (ICC) determined from the empty models (Singer and Willett 2003). To account for temporal autocorrelation, different structures were tested and the one that best fits the data was selected. This selection was based on the Akaike information criterion (AIC) values (low values are preferred, indicating a better fit) using the package "bbmle" (Bolker and Team 2020). The fitted means and standard errors of the germination rate were calculated at each date for each treatment using emmeans package (Lenth 2021) and were used to draw figures using the package ggplot2 (Wickham 2016) in R-4.0.5 software (R Core Team 2021).

\section{Results}

\section{Variability of seeds' mass of $B$. aegyptiaca and $R$. heudelotii in the study zones}

There was a significant variation of the seed mass of both species $(\operatorname{Pr}<2.2 \mathrm{e}-16)$ among the phytodistricts. The seed mass was higher in Atacora chain phytodistrict $(3.12 \pm 0.77 \mathrm{~g})$ but lower in Mekrou-Pendjari $(2.09 \pm 0.55 \mathrm{~g})$ for $B$. aegyptiaca and that of $R$. heudelotii was higher and Plateau phytodistrict $(1.89 \pm 0.40 \mathrm{~g})$ but lower in Pobe $(1.14 \pm 0.48 \mathrm{~g})$ and South Borgou $(1.13 \pm 0.23 \mathrm{~g})$ phytodistricts. The three seed mass classes were $[\mathrm{P} 1(\mathrm{P} \otimes 2 \mathrm{~g}$ and $\mathrm{P} \otimes 0.75 \mathrm{~g}), \mathrm{P} 2(2 \mathrm{~g} \geq \mathrm{P} \otimes 3 \mathrm{~g}$ and $0.75 \mathrm{~g}$ $\geq \mathrm{P} \otimes 1.50 \mathrm{~g}), \mathrm{P} 3(\mathrm{P} \geq 3 \mathrm{~g}$ and $\mathrm{P} \geq 1.50 \mathrm{~g})]$ respectively for $B$. aegyptiaca and $R$. heudelotii (Table 2 ).

\section{Germination capacity of $B$. aegyptiaca and $R$. heudelotii seeds}

Results showed that the seed mass and pre-treatment have a significant effect on the germination capacity of seeds of $B$. aegyptiaca and $R$. heudelotii ( $\mathrm{Pr}<0.05$; Table 3 \& Fig. 2). The heaviest seeds of each species $[P 3(P \geq 3 \mathrm{~g})$ and $P 3(P \geq 1.50 \mathrm{~g})]$ provided the highest germination rates $(73.60 \pm 5.19 \%$ and $62.50 \pm 5.71 \%)$ and the lowest germination rates $(23.60 \pm 5.01 \%$ and $11.10 \pm 3.70 \%)$ with the fewer heavy seeds $[(\mathrm{P} 1(\mathrm{P} \otimes 2 \mathrm{~g})$ and $\mathrm{P} 1(\mathrm{P} \otimes 0.75 \mathrm{~g})]$ for $B$. aegyptiaca and $R$. heudelotii respectively (Fig. 2a,b). In general, for the three mass classes, the germination rates increased continuously over time for classes $\mathrm{P} 3$ and $\mathrm{P} 2$ respectively $(2 \mathrm{~g} \geq \mathrm{P} \otimes 3 \mathrm{~g}$ and $0.75 \mathrm{~g} \geq \mathrm{P} \otimes 1.50 \mathrm{~g})$ ], while for class $\mathrm{P} 1$, the germination rates 
was constant from day-22 and day-20 respectively for $B$. aegyptiaca and $R$. heudelotii (Fig. 2a,b). The seeds scarification with a hammer (T2) gave the first emergence at the day-8 and day-10 and exhibited the highest seed germination rates $(62.00 \pm 4.67 \%$ and $49.10 \pm 4.81 \%)$ compared to pre-treatment T1 which gave germination rates of $50.00 \pm 4.81 \%$ and $35.20 \pm 4.59 \%$ with the first emergence at the day10 and day-13 for $B$. aegyptiaca and $R$. heudelotii respectively (Fig. 2c,d). In short, the results showed that, whatever the phytodistrict, the seeds germinated at relatively constant rates (Pr> 0.05; Table 3; Fig. 2e,f). The block variance is negligible indicating the weak variation due to the blocks (Table 3).

\section{Initial growth of $B$. aegyptiaca seedlings in the nursery}

A significant effect of phytodistrict (provenance) and seed mass on the total height, basal diameter number of leaves and ramifications of $B$. aegyptiaca seedlings was noted. In addition, the total height varied significantly among the pre-treatment techniques $(\operatorname{Pr}<0.05)$. The interactions between the phytodistrict, seed mass and pre-treatment were also significant showing that differences among phytodistricts were not similar across seed masses and pre-treatments. A significant effect of the time on only the number of leaves was noted $(\mathrm{Pr}<0.05)$. The block variance is negligible indicating the weak variation due to the blocks (Table 4). Accordingly, the seeds from North Borgou phytodistrict scarified with a hammer (T2) and the heaviest seeds [P3 ( $P \geq 3 \mathrm{~g})]$ showed the highest total height $(36.43 \pm 1.03 \mathrm{~cm})$ and the highest basal diameter $(2.84 \pm 0.03 \mathrm{~mm})$, the greatest number of leaves (32) and ramifications (1) (Fig. 3). While, the lowest values of total height $(24.34 \pm 0.91 \mathrm{~cm})$, basal diameter $(2.43 \pm 0.04 \mathrm{~mm})$, number of leaves (25) and ramifications ( 0 ) were shown by the seeds from Mekrou-Pendjari phytodistrict and the fewer heavy seeds [P1 $(\mathrm{P} \otimes 2 \mathrm{~g})]$. At the day-28 after sowing the number of leaves was 15 and was in continuous growth until the end of experiment 35 (day-105) (Fig. 3).

\section{Initial growth of $R$. heudelotii seedlings in the nursery}

It was shown that the variation on the total height of $R$. heudelotii seedlings depends only on the interaction between time and seed mass; thus, showing that differences among times were not similar across seed masses $(\operatorname{Pr}<0.05)$. A significant effect of the phytodistrict and seed mass and their interaction were noted $(\mathrm{Pr}<0.05)$. The number of leaves was affected by time, phytodistrict, seed mass and the interaction between phytodistrict and pre-treatment $(\operatorname{Pr}<0.05 ;$ Table 5). In particular, the heaviest seeds [ $P 2(0.75 \mathrm{~g} \geq P \otimes 1.50 \mathrm{~g})$ and $P 3(P \geq 1.50 \mathrm{~g})$ ] showed the highest total height from the day-28 after sowing ( $26.73 \pm 13.56 \mathrm{~cm}$ and $24.23 \pm 7.69 \mathrm{~cm}$ respectively) until the end of experiment (day-105) (150.95 $\pm 13.26 \mathrm{~cm}$ and $151.97 \pm 6.37 \mathrm{~cm}$ respectively) and the lowest (from $9.81 \pm 8.13 \mathrm{~cm}$ at the day-28 to $138.17 \pm 9.79 \mathrm{~cm}$ at the day-105) with the fewer heavy seeds [P1 (Pष0.75 g) (Fig. 4a). In addition, the heaviest seeds (P3) from Pobe phytodistrict showed the highest basal diameter $(12.53 \pm 1.47 \mathrm{~mm})$ and the lowest basal diameter $(2.54 \pm 1.53 \mathrm{~mm})$ with its fewer heavy seeds (P1) (Fig. 4b). At the day-28 after sowing the number of leaves was 04 and reached its mean of 20 at day-105 (Fig. 4c). The heaviest seeds (P3) from Pobe phytodistrict showed also the greatest number of leaves (14), while the fewer heavy seeds (P1) from Plateau and South Borgou phytodistricts and the fewer heavy seeds (P1) showed the lowest number of leaves (10) (Fig. 4d,e). It was not a significant effect of seed pre-treatments (T1 and T2) on 
initial growth of $R$. heudelotii seedlings, with almost no ramifications during the trial period (just a single ramified seedling for the whole).

\section{Discussion}

This study assessed the germination capacity and seedling growth of $B$. aegyptiaca and $R$. heudelotii seeds according to seed provenance, seed mass and pre-treatment techniques in Benin.

This study revealed that the seeds of $B$. aegyptiaca were heavier in Atacora chain phytodistrict but lower in Mekrou-Pendjari. As for $R$. heudelotii, its seeds were heavier in Plateau phytodistrict but lower in Pobe and South Borgou phytodistricts. In addition, the trend of the seed mass recorded was similar across phytodistricts. This showed the representativeness the seed masses and allowed to group them in the three classes. This observation suggested that environmental factors (particularly rainfall) play an important role in determining these seed characteristics as well as the probably genetic factors influence. Several studies revealed plants growing in areas with higher rainfall tend to develop higher seed masses (Hounsou-Dindin et al. 2016; Padonou et al. 2013). Investigations in a controlled environment (provenance test) were therefore necessary to confirm the heritability of the characters observed. If these characters turn out to be highly hereditary, they could be used in the definition of descriptors to characterize the "varieties" or ecotypes which would come to be identified.

The seeds of $B$. aegyptiaca and $R$. heudelotii trees most often take longer to germinate (because of their maturity which comes only at the end of the rainy season), compared to the ones of grasses and other cultivated plants (which mature during the rainy season, e.g., Mangifera indica) which germinate quite quickly, due to various intrinsic factors such as seed coat or physiological dormancy. Our findings were that the seeds scarification with a hammer (T2) gave the first emergence for relatively short times at the $8^{\text {th }}$ and $10^{\text {th }}$ day with the highest seed germination rates $(62.00 \pm 4.67 \%$ and $49.10 \pm 4.81 \%)$ compared to pre-treatment ( $\mathrm{T} 1=$ Soaking the seeds in plain tap water for 72 hours) which gave germination rates of $50.00 \pm 4.81 \%$ and $35.20 \pm 4.59 \%$ with its first emergence at the $10^{\text {th }}$ and $13^{\text {th }}$ days respectively for $B$. aegyptiaca and $R$. heudelotii. These findings were supported by several other studies which showed that germination of species is subject to various constraints, including the germinability which varies according to the technique (or pre-treatment) applied. These results showed that integumentary dormancy hinders the germination of $B$. aegyptiaca and $R$. heudelotii seeds and corroborate those on $B$. aegyptiaca (Boubacar et al. 2018; Kouyaté et al. 2015) and R. heudelotii (Djeugap et al. 2013; Kouame et al. 2012; Moussa et al. 2020) that reported an onset of germination varying from day- 6 to day- 14 . This confirms that seed dormancy of these species is physical and scarification of the seed coat is necessary to promote seed imbibition and germination. In addition, the results revealed highly significant differences $(\operatorname{Pr}<0.05)$ between the germination rate of the seed masses, indicating that the heaviest seeds provided the highest germination rates $(73.60 \pm 5.19 \%$ and $62.50 \pm 5.71 \%)$ and the lowest germination rates $(23.60$ $\pm 5.01 \%$ and $11.10 \pm 3.70 \%)$ were obtained with the fewer heavy seeds [(P1 ( $P \otimes 2 \mathrm{~g})$ and $P 1(\mathrm{P} \otimes 0.75 \mathrm{~g})$ ] respectively for $B$. aegyptiaca and $R$. heudelotii. These results confirm that the large sized seeds germinated faster than smaller seeds (Das et al. 2016; Padonou et al. 2013) due to the quantity of the 
stored reserve of substances. It is important to note that germination rates do not vary significantly from one phytodistrict to another, revealing that seeds collected from one area or another of the country gave satisfactory results. Nevertheless, it is necessary to underline the advantages and disadvantages associated with each pre-treatment technique. For example, the scarification with a hammer (T2) showed a high germination rate but requires more time, manpower (if the seeds are a lot), adequate material (the mass of the hammer and the quality/solidity of the support) and rigorous technicality (proportionality of the intensity of the force exerted on the seed) to avoid crushing the seeds. While soaking the seeds in plain tap water for 72 hours (T1) showed relatively lower rates but easy and not demanding. For this we can recommend T2 for small scale production (less than 100 seeds) and for T1 for small scale production. Finally, we stress the importance of the seed viability test step to effectively guarantee good germination rates and the preferred use of freshly harvested seeds.

Similar trends were found at the level of the initial growth of $B$. aegyptiaca and $R$. heudelotii seedlings. The seeds scarified with a hammer (T2) and the heaviest seeds (P3) showed the highest total height ( $36.43 \pm 1.03 \mathrm{~cm}$ and $151.97 \pm 6.37 \mathrm{~cm})$, basal diameter $(2.84 \pm 0.03 \mathrm{~mm}$ and $12.53 \pm 1.47 \mathrm{~mm})$, the greatest number of leaves (32 and 14) and ramifications (1) respectively for $B$. aegyptiaca and $R$. heudelotii. While the fewer heavy seeds (P1) showed the lowest values. This indicates that the large sized seeds grow faster than smaller seeds. These results join the idea according to which the seed fulfills the role of "pantry" thanks to the reserve substances which it accumulates at the time of its formation, either in the albumen or directly in the cotyledons (Das et al. 2016). All seeds contain reserves that are used by the embryo in the first phase of germination (i.e., before the photosynthetic apparatus is differentiated) and therefore, that the young seedling becomes autotrophic. When a seed germinates, it has only two days (48 hours) before having exhausted its reserves to transform into a seedling capable of photosynthesis (FAO 1992). As the relative speed of use of reserves varies according to the mass of the original seed (Pommel and Bouchard 1990), seedlings from large seeds mobilize in a given time a much greater quantity of reserves, and therefore grow faster than those from small seeds. Seed vigor is an important requirement for good germination and seedlings growth. In small seeds, the reserves still available at the time of the transition to autotrophy are in smaller quantities. However, these constitute a safety margin: seedlings from small seeds will show greater fragility vis-à-vis environmental conditions. Knowledge of the mass of the original seed, which determines the capacity of the seedling to develop and its resistance to environmental conditions, is therefore an essential element in characterizing the performance of a seedling.

The growth of vegetative organs is one of the processes which allow plants to grow and to optimize the surfaces of exchanges with the external environment, characteristics of their strategy of exploitation of resources. Variables measured in seedlings from different provenances revealed significant differences between provenances. Particularly, B. aegyptiaca seeds from North Borgou phytodistrict and those of $R$. heudelotii from Pobe phytodistrict were the one that showed a high growth performance. The variabilities highlighted can be explained by the combined actions of geographic isolation and gene mutation (Diallo et al. 2010). These observed differences indicate that seedlings from these phytodistricts invest more in the growth compared to other provenances. Previous research evidenced the rapid seedling growth is 
more related to genetic factors of parent trees than to soil conditions and structure and environmental factors (Weber et al. 2015) and may serve as a selection trait for genetically superior progeny. Variations in the pre-treatment techniques would be due to the shorter germination times compared to each other, thus offering the advantage to the seedlings from the seeds scarified with a hammer (T2) to grow faster. This solves the problem of the species domestication with more appropriate techniques.

\section{Conclusion}

This study revealed the importance to choose heaviest seeds to facilitate and guarantee a high germination rates of seeds and seedlings growth for Balanites aegyptiaca (seed mass $\geq 3 \mathrm{~g}$ ) and Ricinodendron heudelotii (seed mass $\geq 1.50 \mathrm{~g}$ ). In addition, seeds need to be pre-treated them by scarifying with a hammer or soaking in plain tap water for 72 hours before sowing. Nevertheless, the seeds scarification with a hammer provides high plant production performance in the species. Absolute seedlings growth is proportional to seed size, at least through the establishment phase. This study is of great contribution to the development of income-generating activities for local communities and job providers and soil restoration with agroforestry systems diversification in context of climate change. Future researches should assess the species genetic diversities, biochemical characteristics and the value chains and identify the vegetative propagation techniques of their young plants.

\section{Declarations}

\section{Funding}

This research was supported by the University of Abomey-Calavi (Project 'WILD-OIL /2018/PFCR III/UAC') for a PhD fellowships.

\section{Conflict of interest}

The authors declare that they have no conflict of interest.

\section{Availability of data and materials}

The datasets generated during and/or analysed during the present study are available from the authors upon request.

\section{Acknowledgements}

We are grateful to Djamiou Anago and Valentin Kouhouenou for their significant help during field work. We are also thankful to the local communities for their precious time devoted and their kindly collaboration during data collection.

\section{References}


Adomou AC, Sinsin B, van der Maesen LJG (2006) Phytosociological and chorological approaches to phytogeography: a meso-scale study in Benin Systematics and Geography of Plants 76:155-178

Assogbadjo AE, Glèlè Kakaï R, Edon S, Kyndt T, Sinsin B (2010) Natural variation in fruit characteristics, seed germination and seedling growth of Adansonia digitata L. in Benin New Forests 41:113-125

Bayala J, Sanou J, Teklehaimanot Z, Kalinganire A, Ouédraogo SJ (2014) Parklands for buffering climate risk and sustaining agricultural production in the Sahel of West Africa Curr Opin Environ Sustain 6:28-34 doi:https://doi.org/10.1016/j.cosust.2013.10.004

Bolker B, Team RC (2020) bbmle: Tools for General Maximum Likelihood Estimation. R package version 1.0.23.1. https://CRAN.R-project.org/package=bbmle

Boubacar AA, Douma S, Diouf A, Agúndez MD, Alia R, Mahamane A (2018) Effets du stress hydrique et de la température sur la germination de quatre ligneux alimentaires prioritaires du Niger Afr Sci 14:28-41

Boyle TJB, Cossalter C, Griffin AB (1997) Genetic resources for plantation forestry, pp. 25-63. In: Management of soil, Nutrients and water in tropical plantation Forests, E.K.S., Nambiarand and A.G., Brown, A.G. (eds.), ACIAR, Camberra, Australia

Das M, Nath A, Singnar P, Das A (2016) Effect of Fruit Mass on Germination and Seedling Characteristics of a Tropical Climbing Bamboo Melocalamus compactiflorus J Plant Chem and Ecophysiol 1:1003

Diallo BO, Joly HI, Mc Key D, Hossaert-Mckey M, Chevallier MH (2010) Variation des caractères biométriques des graines et des plantules de neuf provenances de Tamarindus indica $\mathrm{L}$.

(Caesalpinioideae) Fruits 65:153-167

Djeugap F, Bernier L, Dostaler D, Khasa D, Fontem D, Nwaga D (2013) Opportunités et contraintes agroforestières de Ricinodendron heudelotii au Cameroun International Journal of Biological and Chemical Sciences 7:344-355 doi:10.4314/ijbcs.v7i1.30

FAO (1992) Guide de manipulation des semences forestières. Organisation des Nations Unies pour l'alimentation et l'agriculture (FAO), Viale delle Terme di Caracalla, 00100 Rome, Italie. http://www.fao.org/3/AD232F/ad232f00.htm\#TOC

Fredrick C, Muthuri C, Ngamau K, Sinclair F (2015) Provenance variation in seed morphological characteristics and early seedlings growth of Faidherbia albida Journal of Horticulture and Forestry 7:127-140

Hooper DU et al. (2005) Effects of biodiversity on ecosystem functioning: a consensus of current knowledge and needs for future research Ecological Monographs 75:3-35

Hounsou-Dindin G, Assogbadjo AE, Idohou R, Salako VK, Glèlè Kakaï R (2016) Morphological variation of baobab fruits and seeds traits in smallholders farming systems in Benin: a preliminary study on baobab 
leaves production. Fifth African Higher Education Week and RUFORUM Biennial Conference 2016," Linking agricultural universities with civil society, the private sector, governments and other stakeholders in support of agricultural development in Africa", Cape Town, South Africa, 17-21 October 2016; 2016: RUFORUM

Hounsou-Dindin G et al. (2018) Fiche technique pour la culture de feuilles fraîches du baobab (Adansonia digitata L.). Laboratoire de Biomathématiques et d'Estimations Forestières (LABEF), Université d'AbomeyCalavi (UAC), Série Agroforestière No : AGF/001/2018, Abomey-Calavi, Bénin.

Howell N (1981) The effect of seed size and relative emergence time on fitness in a natural population of Impatiens capensis Meerb.(Balsaminaceae) American Midland Naturalist:312-320

Idohou R, Ariño AH, Assogbadjo A, Glèlè Kakaï R, Sinsin B (2015) Knowledge of diversity of Wild Palms (Arecaceae) in the Republic of Benin: finding gaps in the national inventory by combining field and digital accessible knowledge Biodiversity Informatics 10:45-55

Kassambara A, Kosinski M, Biecek P (2021) survminer: Drawing Survival Curves using 'ggplot2'. R package version 0.4.9. https://CRAN.R-project.org/package=survminer

Kouame NDM-T, Gnahoua GM, Mangara A (2012) Essais de germination de Ricinodendron heudelotii (Euphorbiaceae) dans la région du Fromager au centre-ouest de la Côte d'Ivoire Journal of Applied Biosciences 56:4133-4141

Kouyaté AM, Lankoandé B, Ouédraogo A, Diarra I, Coulibaly HT, Lykke AM (2015) Technique de propagation de Balanites aegyptiaca. Fiche technique. Projet QualiTree

Kumar BM, Nair PKR (2011) Carbon Sequestration in Agroforestry Systems Springer, The Netherlands:307 p. doi:http://dx.doi.org/10.1007/978-94-007-1630-8

Lenth RV (2021) emmeans: Estimated Marginal Means, aka Least-Squares Means. R package version 1.6.0. https://CRAN.R-project.org/package $=$ emmeans

McNair J, Sunkara A, Frobish D (2012) How to analyse seed germination data using statistical time-toevent analysis: Non-parametric and semi-parametric methods Seed Science Research 22:77-95 doi:https://doi.org/10.1017/S0960258511000547

Moussa A, Déléké Koko KIE, Fandohan AB (2020) Domestication de Ricinodendron heudelotii (baill.) Pierre ex heckel: savoirs traditionnels, germination et croissance des jeunes plants en milieu contrôlé Rev Ivoir Sci Technol 35 247-269

Padonou EA, Kassa B, Assogbadjo AE, Chakeredza S, Babatoundé B, Glèlè Kakaï R (2013) Differences in germination capacity and seedling growth between different seed morphotypes of Afzelia africana $\mathrm{Sm}$. in Benin, West Africa Journal of Horticultural Science and Biotechnology 88:679-684 
Pinheiro J, Bates D, DebRoy S, Sarkar D, R Core Team (2021) _nlme: Linear and Nonlinear Mixed Effects Models_. R package version 3.1-152, <URL: https://CRAN.R-project.org/package=nlme>

Pommel B, Bouchard C (1990) Influence du poids de la semence et de la profondeur de semis sur la croissance et le développement de la plantule de maïs Agronomie 10:699-706

Quero JL, Villar R, Marañón T, Zamora R, Poorter L (2007) Seed-mass effects in four Mediterranean Quercus species (Fagaceae) growing in contrasting light environments American Journal of Botany 94:1795-1803

R Core Team (2021) R: A language and environment for statistical computing. R Foundation for Statistical Computing, Vienna, Austria. URL https://www.R-project.org/

Samb B, Schiffers B (2003) Origine et impact des risques biologiques, physiques et chimiques Proceedings Bio-Scope-Atelier" Responsable Assurance Qualité Totale"

Singer JD, Willett JB (2003) Applied longitudinal data analysis: Modeling change and event occurrence. Oxford university press,

Therneau T (2021) _A Package for Survival Analysis in R_. R package version 3.2-10, <URL: https://CRAN.R-project.org/package=survival>

Venables WN, Ripley BD (2002) Modern Applied Statistics with S. Fourth Edition. Springer, New York. ISBN 0-387-95457-0. [accessed 9 Nov. 2020]

Weber JC, Montes CS, Kalinganire A, Abasse T, Larwanou M (2015) Genetic variation and clines in growth and survival of Prosopis africana from Burkina Faso and Niger: comparing results and conclusions from a nursery test and a long-term field test in Niger Euphytica 205:809-821

Wickham H (2016) ggplot2: Elegant Graphics for Data Analysis. Springer-Verlag New York

\section{Tables}

Table 1. Factors tested in the frame of the experiment and their modalities. 


\begin{tabular}{|c|c|c|}
\hline \multirow[t]{2}{*}{ Factors } & \multicolumn{2}{|l|}{ Modalities } \\
\hline & B. aegyptiaca & R. heudelotii \\
\hline Phytodistrict & $\begin{array}{l}\text { - Atacora chain } \\
\text { - Mekrou-Pendjari } \\
\text { - North Borgou }\end{array}$ & $\begin{array}{l}\text { - Plateau } \\
\text { - Pobe } \\
\text { - South Borgou }\end{array}$ \\
\hline Seed mass class $(P)$ & $\begin{array}{l}\text { - } \mathrm{P} 1 \\
\text { - } \mathrm{P} 2 \\
\text { - } \mathrm{P} 3\end{array}$ & \\
\hline Pre-treatment $(\mathrm{T})$ & \multicolumn{2}{|c|}{$\begin{array}{l}\text { - } \mathrm{T} 1=\text { Soaking the seeds in plain tap water for } 72 \text { hours } \\
\text { - } \mathrm{T} 2=\text { Scarification with a hammer }\end{array}$} \\
\hline Time (Day) & & \\
\hline Block & & \\
\hline
\end{tabular}

Table 2. Minimum (Min), maximum (Max), means and standard errors (Mean \pm s.e), Probability of significance $(\mathrm{Pr})$ and seed mass class $(\mathrm{P})$ of $B$. aegyptiaca and $R$. heudelotii in the study zones.

\begin{tabular}{|llllll|}
\hline Phytodistrict & Min & Max & Mean \pm s.e & Pr & Seed mass class $(\mathrm{P})$ \\
\hline B. aegyptiaca & & & & & \\
\hline Atacora chain & 1.01 & 5.56 & $3.12 \pm 0.77^{\mathrm{a}}$ & $<2.2 \mathrm{e}-16$ & $\mathrm{P} 1=\mathrm{P} \otimes 2 \mathrm{~g}$ \\
\hline Mekrou-Pendjari & 0.72 & 3.71 & $2.09 \pm 0.55^{\mathrm{c}}$ & $\mathrm{P} 2=2 \mathrm{~g} \geq \mathrm{P} \otimes 3 \mathrm{~g}$ \\
\hline North Borgou & 0.79 & 4.34 & $2.26 \pm 0.74^{\mathrm{b}}$ & $\mathrm{P} 3=\mathrm{P} \geq 3 \mathrm{~g}$ \\
\hline R. heudelotii & & & & & \\
\hline Plateau & 0.49 & 2.84 & $1.89 \pm 0.40^{\mathrm{a}}$ & $<2.2 \mathrm{e}-16$ & $\mathrm{P} 1=\mathrm{P} \otimes 0.75 \mathrm{~g}$ \\
\hline Pobe & 0.46 & 1.81 & $1.14 \pm 0.48^{\mathrm{b}}$ & $\mathrm{P} 2=0.75 \mathrm{~g} \geq \mathrm{P} \otimes 1.50 \mathrm{~g}$ \\
\hline South Borgou & 0.41 & 2.28 & $1.13 \pm 0.23^{\mathrm{b}}$ & $\mathrm{P} 3=\mathrm{P} \geq 1.50 \mathrm{~g}$ \\
\hline
\end{tabular}

Table 3. Effect of factors on the germination probability of B. aegyptiaca and $R$. heudelotii seeds. 


\begin{tabular}{|c|c|c|c|c|c|}
\hline Source & $\beta i$ & $\exp (\beta i)$ & $\operatorname{s.e}(\beta i)$ & z & $\operatorname{Pr}(>|z|)$ \\
\hline \multicolumn{6}{|l|}{ B. aegyptiaca } \\
\hline \multicolumn{6}{|c|}{ Phytodistrict (Ref=Atacora chain) } \\
\hline Mekrou-Pendjari & 0.18 & 1.19 & 0.22 & 0.81 & $0.415 \mathrm{~ns}$ \\
\hline North Borgou & 0.19 & 1.21 & 0.22 & 0.86 & $0.386 n s$ \\
\hline \multicolumn{6}{|c|}{ Seed mass class (Ref=P1) } \\
\hline P2 & 1.42 & 4.15 & 0.28 & 5.05 & $4.2 \mathrm{e}-07 *$ \\
\hline P3 & 1.71 & 5.54 & 0.28 & 6.06 & $1.2 \mathrm{e}-09 *$ \\
\hline \multicolumn{6}{|c|}{ Pre-treatment $(\operatorname{Ref}=\mathrm{T} 1)$} \\
\hline $\mathrm{T} 2$ & 0.54 & 1.73 & 0.18 & 2.97 & $0.003^{*}$ \\
\hline Block (Variance) & & & & 0.01 & \\
\hline \multicolumn{6}{|l|}{ R. heudelotii } \\
\hline \multicolumn{6}{|c|}{ Phytodistrict (Ref=Plateau) } \\
\hline Pobe & -0.00 & 0.99 & 0.25 & -0.00 & $0.993 n s$ \\
\hline South Borgou & -0.21 & 0.81 & 0.25 & -0.81 & $0.417 \mathrm{~ns}$ \\
\hline \multicolumn{6}{|c|}{ Seed mass class $($ Ref $=\mathrm{P} 1)$} \\
\hline P2 & 1.92 & 6.82 & 0.39 & 4.92 & $8.6 \mathrm{e}-07 *$ \\
\hline P3 & 2.10 & 8.20 & 0.38 & 5.45 & $4.7 e-08^{*}$ \\
\hline \multicolumn{6}{|c|}{ Pre-treatment $(\operatorname{Ref}=\mathrm{T} 1)$} \\
\hline $\mathrm{T} 2$ & 0.74 & 2.09 & 0.21 & 3.46 & $0.001 *$ \\
\hline Block (Variance) & & & & 0.07 & \\
\hline
\end{tabular}

Seed mass class $=P 1(P \otimes 2 g$ and $P \otimes 0.75 g), P 2(2 g \geq P \otimes 3 g$ and $0.75 g \geq P \otimes 1.50 g)$ and $P 3(P \geq 3 g$ and $\mathrm{P} \geq 1.50 \mathrm{~g}$ ) respectively for $B$. aegyptiaca and $R$. heudelotii, Pre-treatment technique $=\mathrm{T} 1$ (soaking the seeds in plain tap water for 72 hours) and T2 (scarification with a hammer), Bi=Regression coefficient, exp= Exponentiate=Hazard ratio $(H R)$, s.e $=$ standard error, $z=z$ statistic, $\operatorname{Pr}(>|z|)=$ Probability of significance, $*=$ Significant at $5 \%$, ns $=$ Not significant.

Table 4. Growth dynamic in height, basal diameter and number of leaves and ramifications of $B$. aegyptiaca seedlings. 


\begin{tabular}{|c|c|c|c|c|c|c|c|c|c|}
\hline \multirow[t]{2}{*}{ Source } & \multirow[t]{2}{*}{$\mathrm{df}$} & \multicolumn{2}{|l|}{ Height } & \multicolumn{2}{|c|}{ Basal diameter } & \multicolumn{2}{|c|}{ Number of leaves } & \multicolumn{2}{|c|}{$\begin{array}{l}\text { Number of } \\
\text { ramifications }\end{array}$} \\
\hline & & $\mathrm{F}$ & $\operatorname{Pr}$ & $\mathrm{F}$ & $\operatorname{Pr}$ & Chisq & $\operatorname{Pr}$ & Chisq & $\operatorname{Pr}$ \\
\hline Time & 11 & - & - & - & - & 778.17 & $<2 \mathrm{e}-16^{\star}$ & - & - \\
\hline Phytodistrict & 2 & 32.51 & $<0.001 *$ & 4.50 & $0.011^{\star}$ & 22.72 & $1 e-05^{\star}$ & 15.24 & $0.009 *$ \\
\hline $\begin{array}{l}\text { Seed mass } \\
\text { class }(P)\end{array}$ & 2 & 46.27 & $<0.001 *$ & 66.89 & $<0.001^{\star}$ & 35.74 & $1 e-08^{*}$ & 16.77 & $0.004^{*}$ \\
\hline $\begin{array}{l}\text { Pre- } \\
\text { treatment } \\
\text { (T) }\end{array}$ & 1 & 18.03 & $<0.001 *$ & 13.31 & $0.053 \mathrm{~ns}$ & 0.62 & $0.430 \mathrm{~ns}$ & 14.83 & $0.080 \mathrm{~ns}$ \\
\hline $\begin{array}{l}\text { Phytodistrict } \\
\times \mathrm{P}\end{array}$ & 4 & 26.08 & $<0.001 *$ & 23.94 & $<0.001^{\star}$ & 102.13 & $<2 \mathrm{e}-16^{\star}$ & 11.10 & $0.025^{\star}$ \\
\hline $\begin{array}{l}\text { Phytodistrict } \\
\times \mathrm{T}\end{array}$ & 2 & 29.96 & $<0.001 *$ & 16.22 & $<0.001^{\star}$ & 31.62 & $1 e-07 *$ & 16.46 & $0.000 *$ \\
\hline$P \times T$ & 2 & 13.27 & $<0.001 *$ & 32.04 & $<0.001^{\star}$ & 16.99 & $0.000 *$ & - & - \\
\hline $\begin{array}{l}\text { Block } \\
\text { (Variance) }\end{array}$ & & 0.09 & & 0.03 & & 0.00 & & 0.01 & \\
\hline
\end{tabular}

$\mathrm{df}=$ degree of freedom, $\mathrm{P}=$ Seed mass class, $\mathrm{T}=$ Pre-treatment technique, $\mathrm{df}=$ degree of freedom, $\mathrm{F}=\mathrm{Fisher}$ statistic, Chisq=Chi square statistic, $\operatorname{Pr}=$ Probability of significance, ${ }^{*}=$ Significant at $5 \%, n s=$ Not significant.

Table 5. Growth dynamic in height, basal diameter and number of leaves of $\boldsymbol{R}$. heudelotii seedlings.

\begin{tabular}{|c|c|c|c|c|c|c|c|}
\hline \multirow[t]{2}{*}{ Source } & \multirow[t]{2}{*}{ df } & \multicolumn{2}{|c|}{ Height } & \multicolumn{2}{|c|}{ Basal diameter } & \multicolumn{2}{|c|}{ Number of leaves } \\
\hline & & $\mathrm{F}$ & $\operatorname{Pr}$ & $\mathrm{F}$ & $\operatorname{Pr}$ & Chisq & $\operatorname{Pr}$ \\
\hline Time & 11 & 0.99 & $0.912 \mathrm{~ns}$ & 3.84 & $0.999 \mathrm{~ns}$ & 1080.24 & $<2.2 \mathrm{e}-16^{\star}$ \\
\hline Phytodistrict & 2 & 0.57 & $0.563 \mathrm{~ns}$ & 6.11 & $0.002^{*}$ & 26.12 & $2.1 \mathrm{e}-06^{\star}$ \\
\hline Seed mass class $(P)$ & 2 & 0.88 & $0.413 \mathrm{~ns}$ & 39.33 & $<0.001^{\star}$ & 28.31 & $7.1 \mathrm{e}-07 *$ \\
\hline Pre-treatment $(\mathrm{T})$ & 1 & 0.26 & $0.607 n s$ & 2.59 & $0.107 n s$ & 0.06 & $0.805 \mathrm{~ns}$ \\
\hline Time $\times$ Phytodistrict & 22 & 0.95 & $0.521 \mathrm{~ns}$ & 0.43 & $0.988 \mathrm{~ns}$ & - & - \\
\hline Time $\times \mathrm{P}$ & 22 & 2.14 & $0.002^{*}$ & 0.72 & $0.812 \mathrm{~ns}$ & - & - \\
\hline Phytodistrict $\times \mathrm{P}$ & 4 & 0.43 & $0.786 n s$ & 6.62 & $<0.001^{\star}$ & - & - \\
\hline$P \times T$ & 2 & 2.06 & $0.128 \mathrm{~ns}$ & 6.34 & $0.052 \mathrm{~ns}$ & 40.15 & $1.0 \mathrm{e}-09 *$ \\
\hline Block (Variance) & & 0.03 & & 0.04 & & 0.00 & \\
\hline
\end{tabular}


$d f=$ degree of freedom, $P=$ Seed mass class, $T=$ Pre-treatment technique, $d f=$ degree of freedom, $F=F i s h e r$ statistic, Chisq=Chi square statistic, $\operatorname{Pr}=$ Probability of significance, ${ }^{*}=$ Significant at $5 \%, n s=$ Not significant.

\section{Figures}

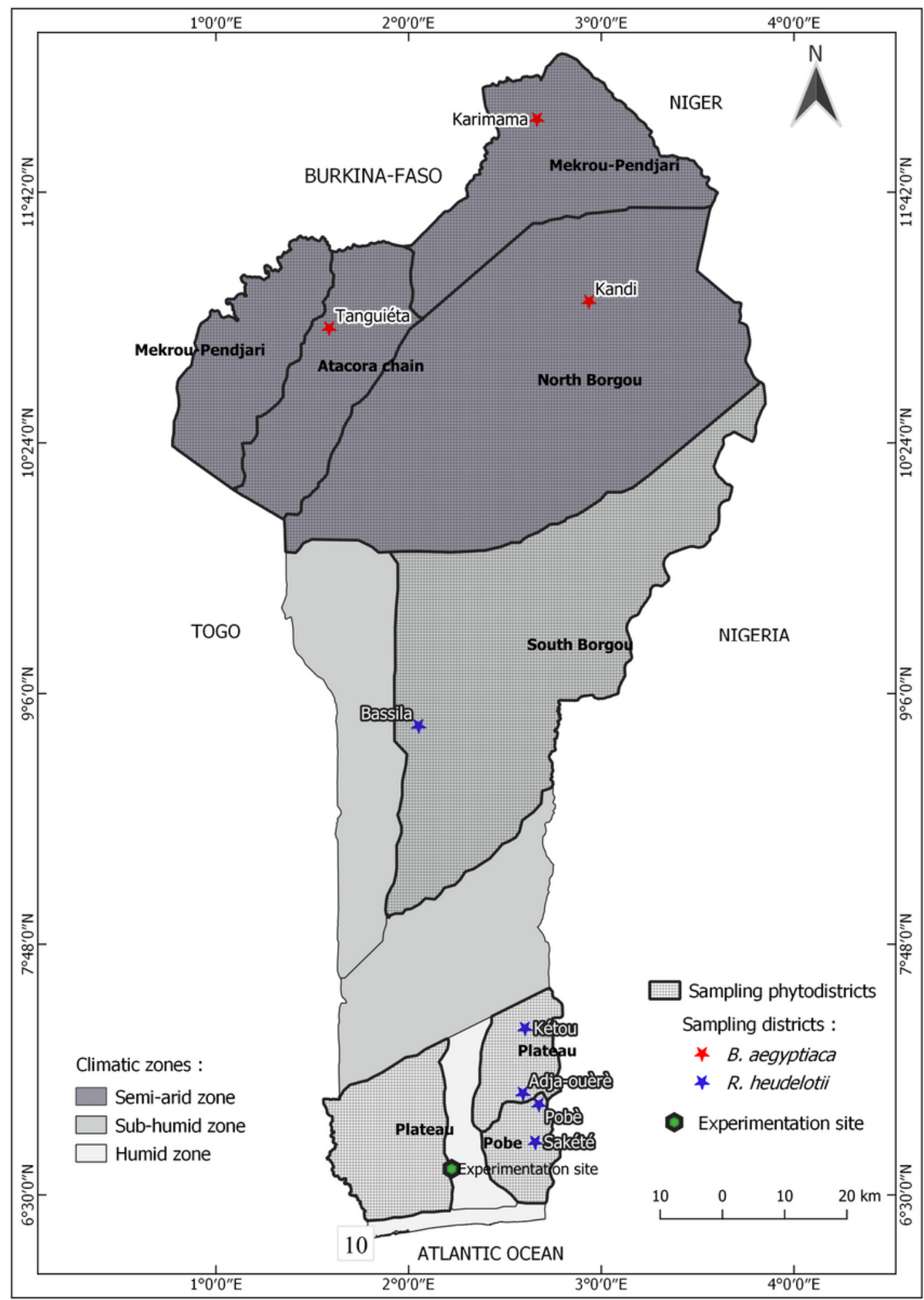

Figure 1 
Benin map showing the geographical location of the localities surveyed for seed collections and the experimentation site.

\section{B. aegyptiaca}

Seed mass class $+\mathrm{P} 1+\mathrm{P} 2+\mathrm{P} 3$

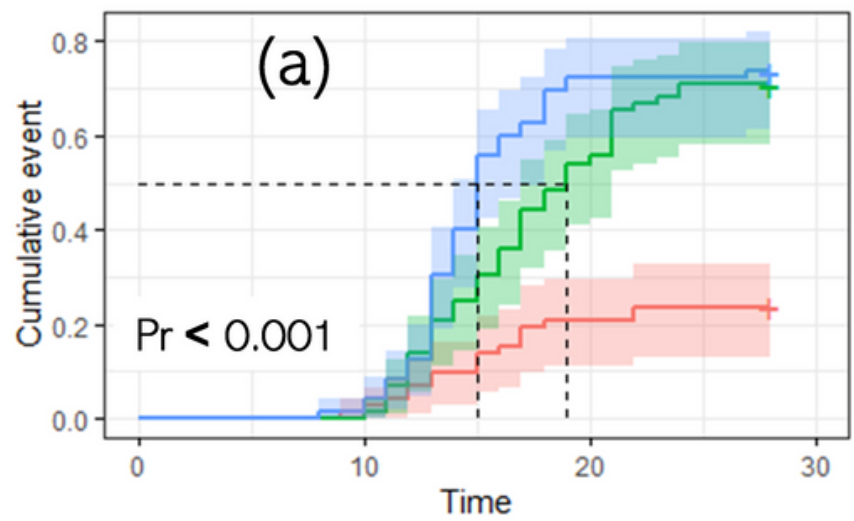

Pre-treatment $\div \mathrm{T} 1+\mathrm{T} 2$

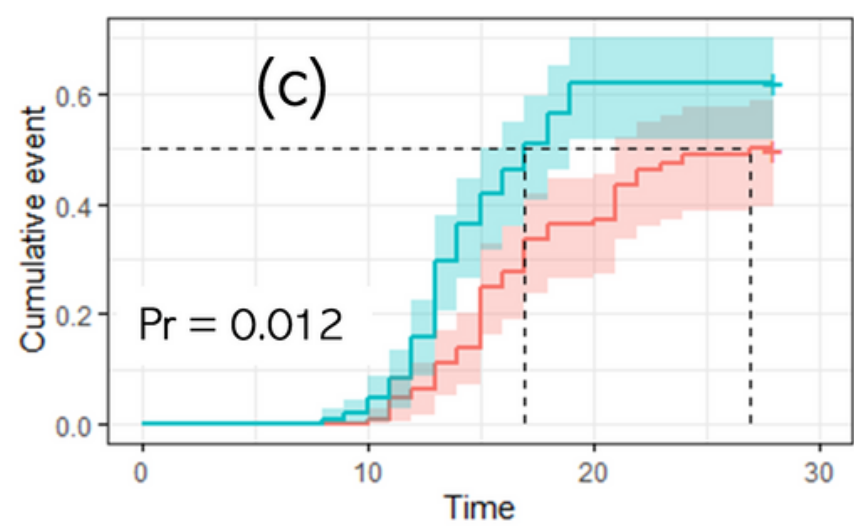

Phytodistrict + AtacoraC $\mp$ MekrouP + NBorgou

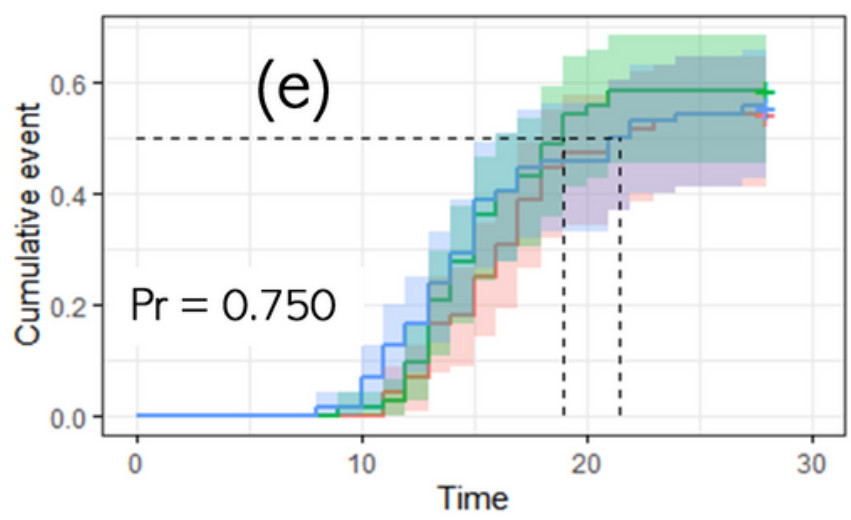

\section{R. heudelotii}

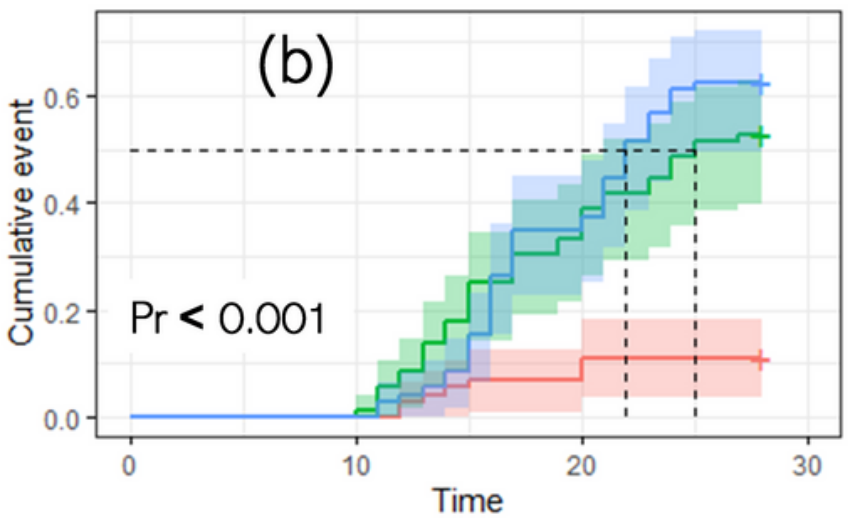

Pre-treatment $+\mathrm{T} 1+\mathrm{T} 2$

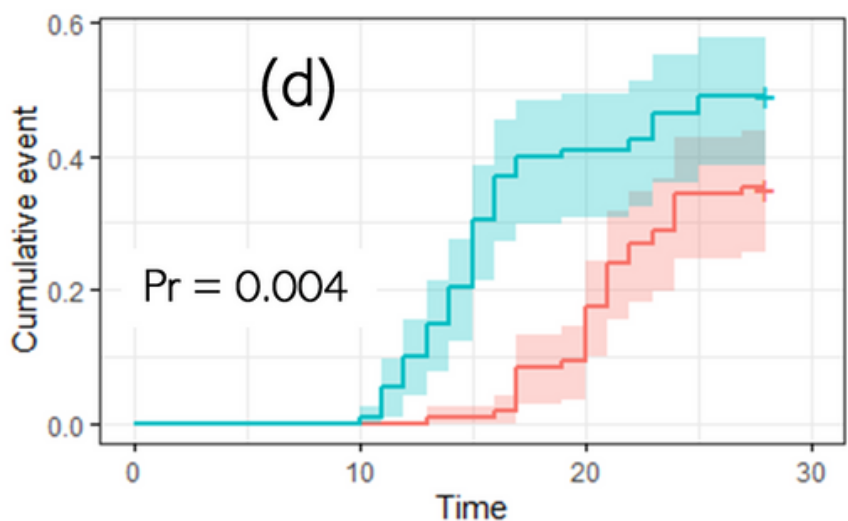

Phytodistrict + Plateau + Pobe + SBorgou

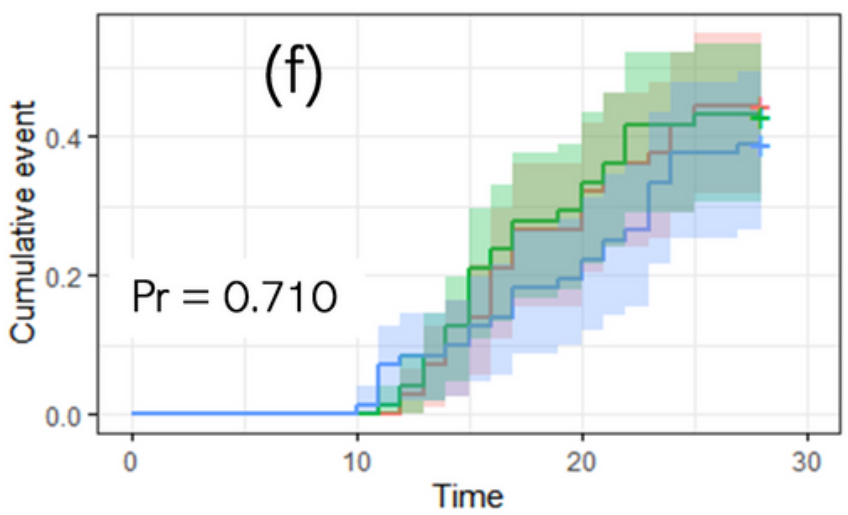

Figure 2

Evolution trend of germination probability (cumulative event) of B. aegyptiaca and R. heudelotii seeds according to the phytodistrict $(a, b)$, seed mass class $(c, d)$ and pre-treatment respectively $(e, f)$. Germination rate $=$ cumulative event value $\times 100$. Seed mass class $=P 1(P \otimes 2 \mathrm{~g}$ and $P \otimes 0.75 \mathrm{~g}), \mathrm{P} 2(2 \mathrm{~g} \geq \mathrm{P} \otimes 3 \mathrm{~g}$ and 
$0.75 \mathrm{~g} \geq \mathrm{P} \otimes 1.50 \mathrm{~g})$ and $\mathrm{P} 3(\mathrm{P} \geq 3 \mathrm{~g}$ and $\mathrm{P} \geq 1.50 \mathrm{~g})$ respectively for $\mathrm{B}$. aegyptiaca and R. heudelotii, Pretreatment technique $=\mathrm{T} 1$ (soaking the seeds in plain tap water for 72 hours) and T2 (scarification with a hammer), Time= day.
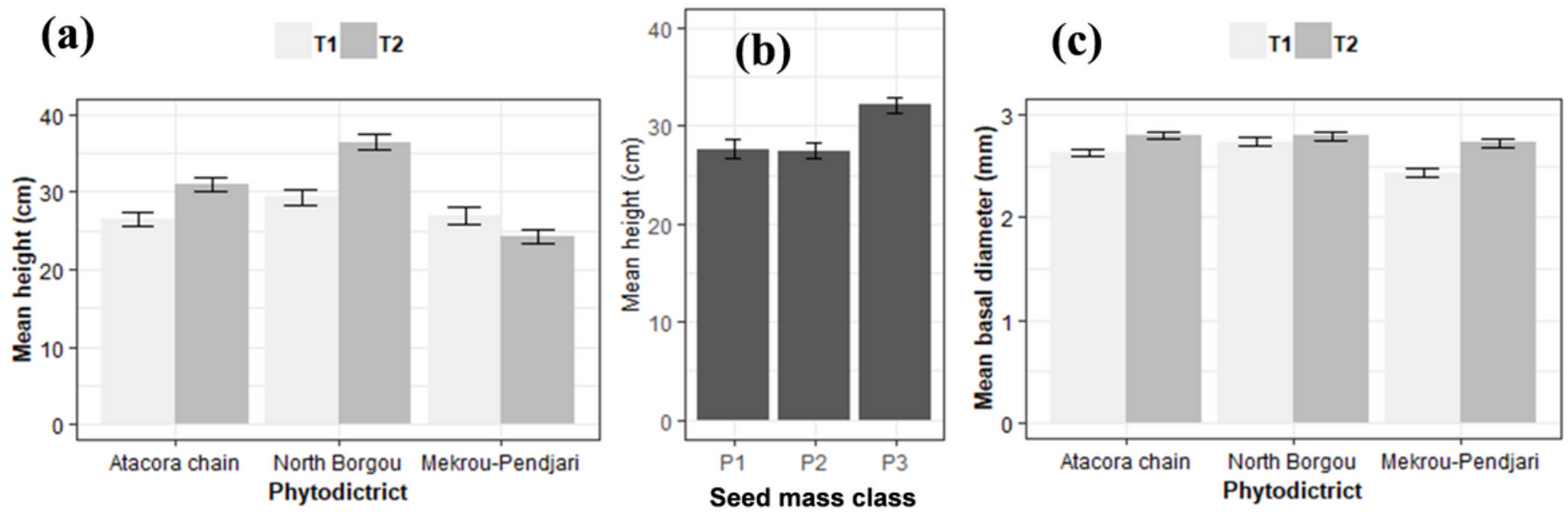

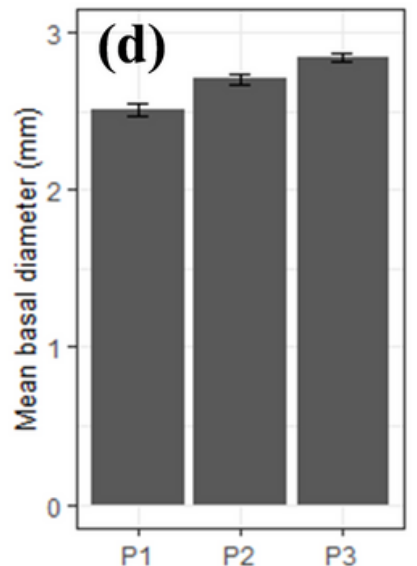

Seed mass class

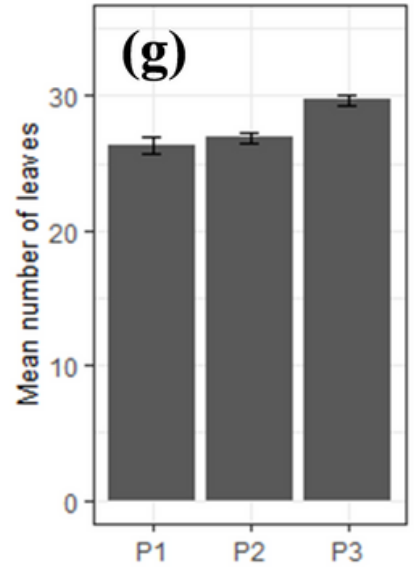

Seed mass class
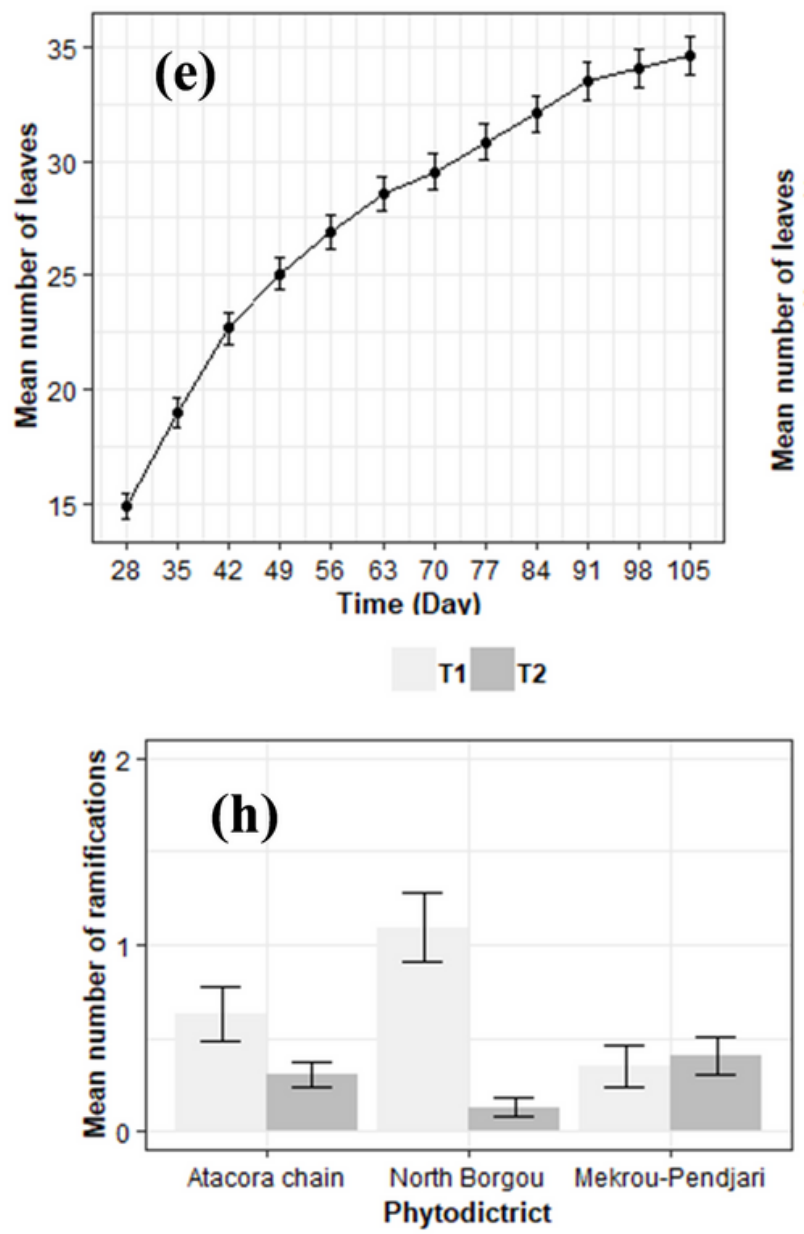

(f)
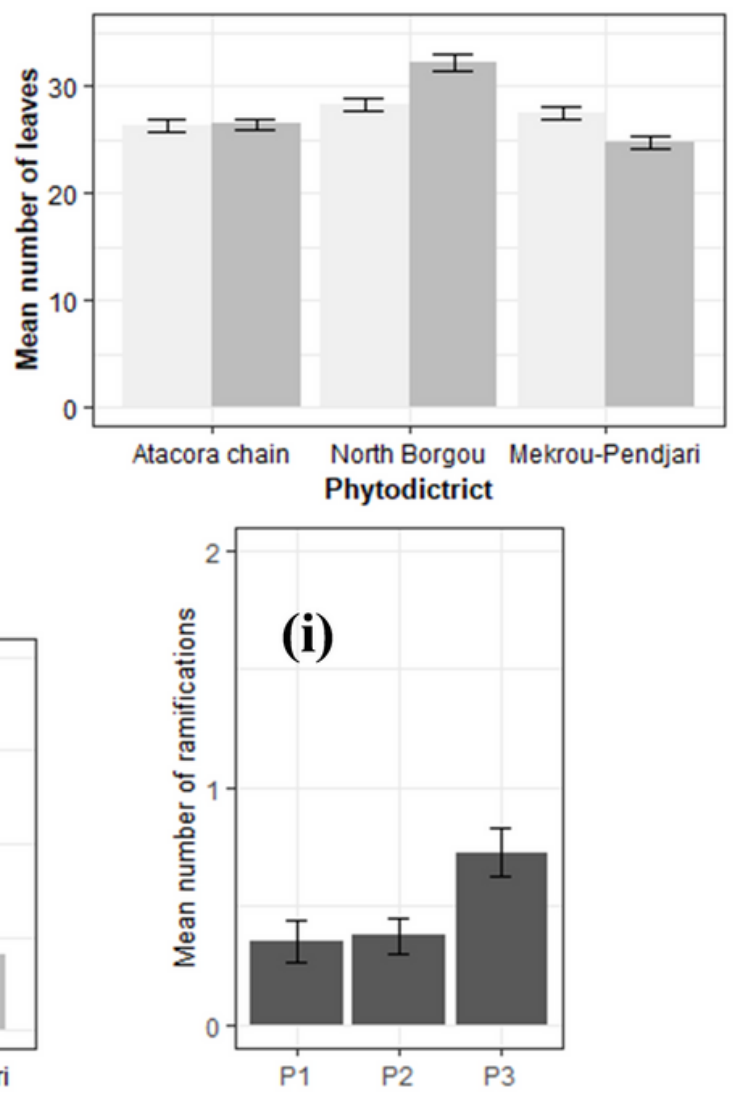

Seed mass class

\section{Figure 3}

Evolution trend of the height $(a, b)$, basal diameter $(c, d)$ and number of leaves $(e, f, g)$ and ramifications $(h, i)$ of $B$. aegyptiaca seedlings at the end of experiment (day-105). Seed mass class $=P 1$ ( $P \otimes 2 \mathrm{~g}$ and $\mathrm{P} \otimes 0.75$ g), $P 2(2 \mathrm{~g} \geq \mathrm{P} \otimes 3 \mathrm{~g}$ and $0.75 \mathrm{~g} \geq \mathrm{P} \otimes 1.50 \mathrm{~g})$ and $\mathrm{P} 3(\mathrm{P} \geq 3 \mathrm{~g}$ and $\mathrm{P} \geq 1.50 \mathrm{~g})$ respectively for $\mathrm{B}$. 
aegyptiaca and R. heudelotii, Pre-treatment technique $=\mathrm{T} 1$ (soaking the seeds in plain tap water for 72 hours) and T2 (scarification with a hammer).
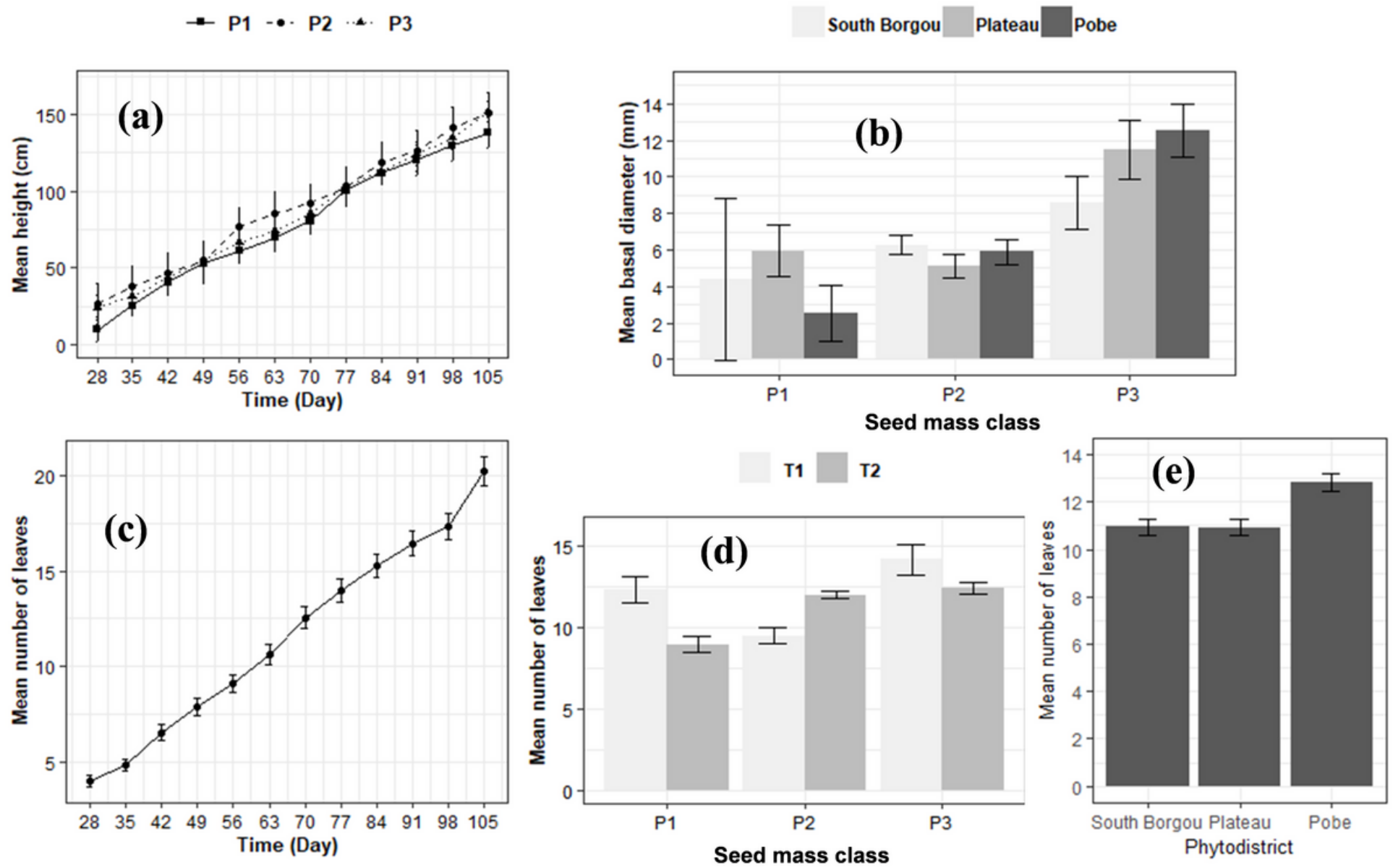

Figure 4

Evolution trend of the height $(a)$, basal diameter $(b, c)$ and number of leaves $(d, e, f)$ of R. heudelotii seedlings at the end of experiment (day-105). Seed mass class $=P 1(P \otimes 2 \mathrm{~g}$ and $\mathrm{P} \otimes 0.75 \mathrm{~g}), \mathrm{P} 2(2 \mathrm{~g} \geq \mathrm{P} \otimes$ $3 \mathrm{~g}$ and $0.75 \mathrm{~g} \geq \mathrm{P} \otimes 1.50 \mathrm{~g})$ and $\mathrm{P} 3(\mathrm{P} \geq 3 \mathrm{~g}$ and $\mathrm{P} \geq 1.50 \mathrm{~g})$ respectively for $\mathrm{B}$. aegyptiaca and $\mathrm{R}$. heudelotii, Pre-treatment technique $=\mathrm{T} 1$ (soaking the seeds in plain tap water for 72 hours) and T2 (scarification with a hammer).

\section{Supplementary Files}

This is a list of supplementary files associated with this preprint. Click to download.

- Appendix.png 